\title{
Nutrition Counseling Need in Burn Patients
}

\author{
Kiki Lukman, Hardisiswo Soedjana, Rani Septrina, Lisa Hasibuan, Selvy Harianti \\ Division of Plastic Surgery, Department of Surgery Faculty of Medicine Universitas Padjadajaran \\ Dr. Hasan Sadikin General Hospital, Bandung, Indonesia
}

\begin{abstract}
Burns can increase metabolic responses of the sufferers, making adequate nutrition important for burn patients and needs to be considered in the management of burns. Counseling on the importance of nutrition for burn patients can reduce the risk of burn complications. This study was an intervention study designed to increase the community's knowledge and awareness of the importance of nutrition in burn patients. In this study, a lecture session and discussion session on nutrition in burn patients were held by the Division of Plastic Surgery, Department of Surgery, Dr. Hasan Sadikin General Hospital, Bandung, Indonesia at the Jatinangor Public Health Center, Sumedang, Indonesia, on August 14, 2019. Of all participants attending this event, thirty-one participants who participated in through the whole agenda of this event were sampled to be the respondents. Data were collected using a pre- and post-test questionnaires consisting of items on basic knowledge, first treatment, and nutrition for burn patients. More women (74\%) participated in this study. Most respondents were over 40 years old (39\%) and graduated from senior high school (39\%). There was a significant increase in knowledge of the respondents before and after counseling the nutrition of burn patients $(p<0.05)$. Thus, counseling is proven to increase knowledge in the general population that it should be performed routinely in various areas.
\end{abstract}

Key words: Burns, health promotion, knowledge, nutrition

\section{Perlunya Penyuluhan Nutrisi Pada Pasien Luka Bakar}

\begin{abstract}
Abstrak
Luka bakar dapat meningkatkan respons metabolik penderitanya. Nutrisi adekuat pada pasien luka bakar merupakan hal yang cukup penting dan perlu diperhatikan dalam penatalaksanaan luka bakar. Penyuluhan tentang pentingnya nutrisi untuk pasien luka bakar dapat mengurangi risiko komplikasi luka bakar. Penelitian ini adalah studi intervensi yang dirancang untuk meningkatkan pengetahuan dan kesadaran masyarakat tentang pentingnya nutrisi pada pasien luka bakar. Dalam penelitian ini, sesi kuliah dan sesi diskusi tentang nutrisi pada pasien luka bakar diadakan oleh Divisi Bedah Plastik, Departemen Bedah, Rumah Sakit Umum Dr. Hasan Sadikin, Bandung, Indonesia di Pusat Kesehatan Masyarakat Jatinangor, Sumedang, Indonesia, pada 14 Agustus 2019. Dari semua peserta yang menghadiri acara ini, tiga puluh satu peserta yang berpartisipasi melalui seluruh agenda acara ini dijadikan sampel untuk menjadi responden. Data dikumpulkan menggunakan kuesioner sebelum dan sesudah tes yang terdiri atas pengetahuan dasar, pengobatan pertama, dan nutrisi untuk pasien luka bakar. Lebih banyak perempuan (74\%) yang berpartisipasi dalam penelitian ini. Sebagian besar responden berusia di atas 40 tahun (39\%) dan lulus dari sekolah menengah atas (39\%). Ada peningkatan yang signifikan dalam pengetahuan responden sebelum dan sesudah penyuluhan nutrisi pasien luka bakar $(\mathrm{p}<0,05)$. Simpulan, penyuluhan terbukti meningkatkan pengetahuan masyarakat bahwa itu harus dilakukan secara rutin di berbagai bidang.
\end{abstract}

Kata kunci: Luka bakar, nutrisi, pengetahuan, penyuluhan

Corresponding Author: Kiki Lukman, Division of Plastic Surgery, Department of Surgery Faculty of Medicine Universitas Padjadajaran/Dr. Hasan Sadikin General Hospital, Bandung, Jalan Pasteur No. 38 Bandung, est Java, Indonesia, Email: kiki. lukman@unpad.ac.id 


\section{Introduction}

Burn is one of the most common accidents in low and middle-income countries. It is the fourth leading traumatic event in the world after traffic accidents, falls, and violence among individuals. ${ }^{1}$ Burn has become one of the major causes of morbidity and mortality and may result in substantial physical, psychological, and economic losses. ${ }^{2}$ Burns caused approximately 180,000 deaths annually and the leading cause of disability-adjusted life-years (DALYs) lost in low- and middle-income countries. ${ }^{3,4}$

Severe burns may affect almost every organ system. Inflammation, hypermetabolism, muscle wasting, and insulin resistance are all hallmarks of the pathophysiological responses to severe burns. ${ }^{5}$ As oneofthepathophysiological responses, increased metabolism may continue for several years as is marked by increased heart rate, body temperature, calorie consumption, proteolysis, and gluconeiogenesis in order to heal wounds. ${ }^{6,7}$ Failure to meet the nutritional requirements may result in impaired wound healing, multiorgan dysfunctions, increased susceptibility to infection, and death. Failure to provide sufficient calories superimposes starvation over a state of hypercatabolism, resulting in devastating loss of lean body mass and depletion of the available protein-energy pool to meet the pressing needs of wound healing, mucosal integrity, and basic immunologic defenses. Therefore, aggressive nutrition support is essential to ensure adequate burn care, attenuate the hypermetabolic response, optimize wound healing, minimize devastating catabolism, and reduce morbidity and mortality. ${ }^{8}$

Peck et al. ${ }^{1}$ studied 27 severe burn injury patients and found that early enteral nutrition or late enteral nutrition has no significant effect on the mortality rate and no difference in energy expenditure. On the other hand, a randomized study by 9 . Mandell et al. ${ }^{9}$ on 688 children with burn injury shows different results. In this study, early enteral nutrition group shows a decrease in hospital stay and mortality by 8.5\%. Meanwhile, the late enteral nutrition group only shows a decrease in mortality by $12 \%$. Currently, no standardized nutrition support guideline exists for burn patients. There are only recommendations that include high carbohydrate/high glucose intake, high protein/amino acid intake, and a low-fat diet with an emphasis on unsaturated fatty acids to attenuate the catabolic and pathological mechanisms following burns. ${ }^{10}$ Studies have shown that certain specific nutrients exert immune-enhancing effects, particularly in burn patients. These include amino acids such as glutamine and arginine. Overall, the importance of nutritional support in burn patients needs to be emphasized to maintain the homeostasis and vital functions of the patient and to prevent related complications. ${ }^{7}$

Therefore, the researchers in this study conducted a counseling event on the importance of nutrition in burn patients to increase knowledge and awareness of the general public which will eventually reduce the risk of burn complications due to the metabolic response in burn patients.

\section{Methods}

This interventional study was conducted on August 14, 2019. Data were collected in Jatinangor Public Health Center, Sumedang, Indonesia, where people seeking treatment were included as participants. Participants were excluded if they did not participate in the whole event, or did not complete either the pre- or posttest questionnaires. Data collection techniques that were used in this study are primary data.

This event consisted of a lecture session and discussion session provided by the Division of Plastic Surgery, Department of Surgery of Dr. Hasan Sadikin General Hospital Bandung, Indonesia. The counseling was performed by a senior plastic surgeon and medical doctors. Topics in the lecture sessions were basic knowledge of burns, first aid for burn patients, nutrition in burn patients, and complications that may occur in burn patients.

The questionnaire was developed in Indonesian to make it easier for the participants to read and understand. The questionnaire consisted of eleven questions in 3 types of questions; basic knowledge of burns, first aid in burn patients, and nutrition needed for burn patients. The results from the pre- and posttest questionnaires were compared to see the improvement of participants' knowledge of the importance of nutrition in burn patients. Data obtained were analyzed using the McNemar and Wilcoxon signed-rank test.

\section{Results}

In this study, 38 participants attended counseling with 7 of 38 did not attend the whole event and 
Table 1 Demographic Characteristics of Participants

\begin{tabular}{|c|c|c|}
\hline Characteristics & $\begin{array}{c}\text { Number of } \\
\text { Respondent } \\
\text { (persons) }\end{array}$ & $\begin{array}{c}\text { Percentage } \\
\text { (\%) }\end{array}$ \\
\hline \multicolumn{3}{|l|}{ Gender } \\
\hline Male & 8 & 26 \\
\hline Female & 23 & 74 \\
\hline \multicolumn{3}{|l|}{ Age (years old) } \\
\hline$<20$ & 5 & 16 \\
\hline $21-30$ & 5 & 16 \\
\hline $31-40$ & 9 & 29 \\
\hline$>40$ & 12 & 39 \\
\hline \multicolumn{3}{|l|}{ Education } \\
\hline $\begin{array}{l}\text { No formal } \\
\text { education }\end{array}$ & 0 & 0 \\
\hline $\begin{array}{l}\text { Elementary } \\
\text { School }\end{array}$ & 3 & 10 \\
\hline $\begin{array}{l}\text { Junior High } \\
\text { School }\end{array}$ & 7 & 23 \\
\hline $\begin{array}{l}\text { Senior high } \\
\text { School }\end{array}$ & 12 & 39 \\
\hline Higher education & 9 & 29 \\
\hline \multicolumn{3}{|l|}{ Occupation } \\
\hline Unemployed & 13 & 42 \\
\hline $\begin{array}{l}\text { Government } \\
\text { employee }\end{array}$ & 6 & 19 \\
\hline Private employee & 4 & 13 \\
\hline Others & 8 & 26 \\
\hline
\end{tabular}

only filled in the pre-test. Thirty-one participants joined the whole event at the Jatinangor Public Health Center on August 14, 2019. The majority of the participants were women $(74 \%)$ and aged above 40 years old (39\%). Most participants graduated from senior high school and college (68\%) (Table 1).

Evaluation of the level of participants' knowledge was about basic knowledge, first aid, and nutrition for burn patients. All participants who attended the event answered the pre-test and post-test questionnaires. The table below illustrates all participants' responses (Table 2). Based on the table, it is apparent that the participants' knowledge has increased. The test results show that there was a significant difference between pre-test and post-test $(\mathrm{p}<0.001)$.

The pre-test and post-test questionnaires consisted of three components: general knowledge of burns, first aid in burn patients, and nutrition needed for burn patients. The pre-test results of general knowledge of burn data shows that more than $50 \%$ of the participants had general knowledge about burns, and although there was an increase in knowledge of burns, this was not significant, except for questions about complications in burn patients (Table 3).

In the second section on first aid for burn patients, more than $50 \%$ of the participants also answered the pre-test correctly. However, 2 questions showed a significant difference in results; the question about the first thing to do for patients with burnt clothes and first aid in burn patients (Table 3).

The third session of the questionnaire contained items on nutrition for burn patients. In the pre-test, it appeared that less than $50 \%$ of the participants still had poor knowledge about nutrition in burn patients. There is a significant difference in the results of the questions on the composition of a good diet and dietary restrictions for burn patients (Table 3).

\section{Discussion}

This study aimed to determine the knowledge of lay people about burns, first aid in burn patients, and nutrition needed for burn patients as well as the effectiveness of a public health promotion event in improving knowledge. From the demographic data, most of the participants in this study were female (74\%) and aged over

Table 2 Overview of Pre-Test and Post-Test Results

\begin{tabular}{lccc}
\hline & Pre-test & Post-test & P-value \\
\hline Mean & 6.0625 & 8.0313 & \\
Std. Deviation & 2.60195 & 2.03968 & \\
Median & 7.0000 & 8.0000 & \\
Range & $1-9$ & $3-11$ & 0.000 \\
\hline
\end{tabular}


Table 3 Pre-test and Post-test Results on General Knowledge of Burn, First Aid in Burn Patients, and Nutrition in Burn Patients

\begin{tabular}{|c|c|c|c|c|c|}
\hline \multirow{2}{*}{ Questionnaire Item (Correct Answer) } & \multicolumn{2}{|c|}{ Pre-Test } & \multicolumn{2}{|c|}{ Post-Test } & \multirow{2}{*}{ p-value* } \\
\hline & $\mathbf{n}$ & $\%$ & $\mathbf{n}$ & $\%$ & \\
\hline \multicolumn{6}{|l|}{ General Knowledge of Burn } \\
\hline Which of the following is the cause of burns? & 22 & 71 & 28 & 90 & $(0.070)$ \\
\hline $\begin{array}{l}\text { Which of the following is the true statement about } \\
\text { burns? }\end{array}$ & 17 & 55 & 20 & 65 & $(0.549)$ \\
\hline What is the complication of burns? & 19 & 61 & 25 & 81 & $(0.031)^{*}$ \\
\hline \multicolumn{6}{|l|}{ First Aid in Burn Patients } \\
\hline $\begin{array}{l}\text { What is the main thing to do in a patient with a burn } \\
\text { condition? }\end{array}$ & 10 & 32 & 15 & 48 & $(0.227)$ \\
\hline What is the first thing to do if the clothes are on fire? & 22 & 71 & 29 & 94 & $(0.016)^{*}$ \\
\hline $\begin{array}{l}\text { Which of the following are the conditions for } \\
\text { patients who need to be taken to the hospital }\end{array}$ & 25 & 81 & 25 & 81 & $(1.000)$ \\
\hline What is the first aid for burn patients? & 16 & 52 & 28 & 90 & $(0.002)^{*}$ \\
\hline \multicolumn{6}{|l|}{ Nutrition in Burn Patients } \\
\hline $\begin{array}{l}\text { Which of the following is the result of poor nutrition } \\
\text { in the process of healing burns? }\end{array}$ & 20 & 65 & 23 & 74 & $(0.453)$ \\
\hline What is the best diet composition for burn patients? & 11 & 35 & 21 & 68 & $(0.006)^{*}$ \\
\hline $\begin{array}{l}\text { What is the food that must be avoided in burn } \\
\text { patients? }\end{array}$ & 12 & 39 & 22 & 71 & $(0.013)^{*}$ \\
\hline Which of the following contains most protein? & 10 & 32 & 12 & 39 & $(0.754)$ \\
\hline $\begin{array}{l}\text { Which of the following is the result of poor nutrition } \\
\text { in the process of healing burns? }\end{array}$ & 20 & 65 & 23 & 74 & $(0.453)$ \\
\hline
\end{tabular}

*Analyzed with McNemar Test

40 years old (39\%). Most of the participants have no occupation, which might be influenced by the fact that the event was conducted during working hours. The sex distribution of Jatinangor residents is uneven; this is because most of the males work outside the town. ${ }^{11}$ The majority of the participants were senior high school graduates.

The low scores of the pre-event questionnaire show the lack of knowledge of burn, first aid of burn, and nutrition for burn patients in the community. Only $61 \%$ of participants had knowledge about complications of burns while $52 \%$ had knowledge on the first aid for burn patients with less than half knew about the main thing to do in burning condition (32\%), and the type of food that must be avoided in burn patients (35\%). After the one-day health promotion event, the post-event questionnaire score increased significantly with more than $70 \%$ correct answers for all questions. The lack of awareness is prominent in population with lower education. Furthermore, other literature also stated that demographics that are strongly associated with burnt in communities with high population density, lower literacy level, and lower economic level. ${ }^{12}$

Overall, the community knowledge on general information of burns is already sufficient. This can be seen from the percentage of correct answers to the 3 questions about general knowledge, i.e. more than $50 \%$ of the participants answered the pre-test questions correctly. Only 1 question concerning complication of burns has a significant 
result (p-value $=0.031$ ). The complications of burn injury should be understood by the community. It may include infection that may lead to a bloodstream infection (sepsis); fluid loss, including low blood volume (hypovolemia); low body temperature (hypothermia); breathing problems from the intake of hot air, or smoke; cardiovascular effects; renal impairment; and skeletal muscle effects. ${ }^{5}$ This is important as it will affect the decision in the first aid to be given after a fire and to prevent worsening due to burns.

In terms of the questions regarding first aid in burn patients, only 2 questions received a significant difference in the results: the question about the first thing to do for patients with burnt clothes and first aid in burn patients. This means the community has improved significantly in knowledge about first aid for burn injury. Knowledge of first aid is important, as it is widely established that initial first aid can significantly improve burn outcomes and reduce associated pain. It is shown that in some countries, many people reported that they still use traditional common household products such as oils, pastes, powders, honey, and raw egg for the first-aid treatment of burns. Most of these are not beneficial and made secondary treatment by the physician more difficult. ${ }^{13}$ From the results above, half of the respondents did not know about first aid in burn patients. It is similar to a study by Alqahtani et al. on 390 individuals in the Majmaah community, showing that only $10 \%$ of the respondents have the knowledge to give water properly. Almost all participants in the study (98.5\%) sought medical assistance directly. ${ }^{14}$ According to the global reports, community first aid knowledge for burns is rather limited, especially in developing and underdeveloped countries. ${ }^{15,16,17}$ A study by Graham et al. that investigated knowledge of parents in Southern of Yorkshire, Britain indicated and found that less than half of the parents are aware of the first aid for burns. ${ }^{18}$

In addition, in the knowledge of nutrition in burn patients, there is a significant difference in the results on the question of good dietary composition and dietary restrictions that should be avoided in burn patients. Less than $50 \%$ of the participants answered the pre-test questions correctly. This means that nutrition for burn patients is still an unknown topic among lay people. This topic is considered a more advanced category of questions but is important because the ability to know the importance of nutrition in burn cases will affect the outcome of burns.
The constant counseling on the nutritional requirements for burn patients reveals a promising future for improving the quality of care. Nutrition occupies a central role in our lives and, for this reason, it should be approached seriously especially in pathological states. ${ }^{11}$

The significant improvements in the knowledge of the community about burn are consistent with the impacts seen in other intervention studies, where a simple community health education event leads to an improvement of knowledge. Overall, there was a significant improvement in this study $(\mathrm{p}<0.001)$. A similar study that also involves a one-day education event in Egypt to educate mothers on possible home injuries in preschool children was able to show an increase to 18.90 from 10.21 in the total score. ${ }^{19}$

In conclusion, knowledge regarding basic knowledge of burn, first aid in burns, and nutrition in burns has improved significantly after a one-day health promotion, showing the effectiveness of this type of approach. It is then suggested that this type of program should be performed and researched more often by involving a larger population sample, especially in areas prone to fire in Indonesia, in order to provide better care and improve the recovery rate of burn patients. Limitations of this study included a small sample size and decreased focus of some participants because they were waiting for their appointment at the clinic. There is still a limited amount of literature that discusses public knowledge of the importance of nutrition in burn patients. Significant changes are not to be expected without taking action in the form of product modification and environmental/ legislation change.

\section{References}

1. Peck MD, Jeschke M. Epidemiology of burn injuries globally. Burns. 2011;37(7):1087274.

2. Elsous A, Ouda M, Mohsen S, Al-Shaikh M, MokayadS, Abo-Shaban N, etal.Epidemiology and outcomes of hospitalized burn patients in Gaza Strip: a descriptive study. Ethiop J Health Sci. 2016;26(1):9-16.

3. WHO. WHO Health Estimates 2014 Summary Tables: Deaths and global burden of disease. Geneva: WHO; 2014.

4. WHO. Violence, injuries and disability: biennial report 2010-2011. Geneva: WHO; 2012. Available from: https://apps.who.int/ 
iris/handle/10665/75573.

5. Nielson CB, Duethman NC, Howard JM, Moncure M, Wood JG. Burns: pathophysiology of systemic complications and current management. J Burn Care Res. 2017;38(1):e469-81.

6. Mendonça Machado N, Gragnani A, Masako Ferreira L. Burns, metabolism and nutritional requirements. Nutr Hosp. 2011;26(4):692700.

7. Clark A, Imran J, Madni T, Wolf SE. Nutrition and metabolism in burn patients. Burns Trauma. 2017;5:11.

8. Sinwar PD. Nutrition in burn patient. J Mahatma Gandhi Inst Med Sci. 2016;21:8-11

9. Mandell SP, Gibran NS. Early enteral nutrition for burn injury. Adv Wound Care (New Rochelle). 2014;3(1):64-70.

10. Abdullahi A, Jeschke MG. Nutrition and anabolic pharmacotherapies in the care of burn patients. Nutr Clin Pract. 2014; 29(5):621-30

11. Hayati K, Sofiatin Y, Rahayuningsih SE, Roesli RM. Familial Analysis of Patients with Hypertension in Jatinangor, West Java, Indonesia. AMJ. 2017;4(3):449-55.

12. Van der Merwe AE, Steenkamp WC. Prevention of burns in developing countries. Ann Burns Fire Disasters. 2012;25(4):18891.

13. Alomar M, Al Rouqi F, Eldali A. Knowledge, attitude, and belief regarding burn first aid among caregivers attending pediatric emergency medicine departments. Burns. 2016;42(4):938-43.

14. AlQahtani FA, Alanazi MA, Alanazi MK, Alshalhoub KS, Alfarhood AA, Ahmed SM. Knowledge and practices related to burn first aid among Majmaah community, Saudi Arabia. J Family Med Prim Care. 2019;8(2):594-8.

15. Nguyen NL, Gun RT, Sparnon AL, Ryan P. The importance of immediate cooling-a case series of childhood burns in Vietnam. Burns. 2002;28(2):173-6.

16. Lam NN, Dung NT. First aid and initial management for childhood burns in Vietnam-an appeal for public and continuing medical education. Burns. 2008; 34(1):67-70.

17. Kattan AE, AlShomer F, Alhujayri AK, Addar A, Aljerian A. Current knowledge of burn injury first aid practices and applied traditional remedies: a nationwide survey. Burns Trauma. 2016;4:37.

18. Graham HE, Bache SE, Muthayya P, Baker J, Ralston DR. Are parents in the UK equipped to provide adequate burns first aid?. Burns. 2012;38(3):438-43.

19. El Seifi OS, Mortada EM, Abdo NM. Effect of community-based intervention on knowledge, attitude, and self-efficacy toward home injuries among Egyptian rural mothers having preschool children. PLoS One. 2018;13(6):e0198964. 